\title{
Electroacupuncture Applied to LR2 Ameliorates Pain Behavior in The Rat Model of Inflammatory Pain
}

\author{
Sungtae Koo ${ }^{1,2}$, Woo Young Choi ${ }^{2}$ \\ ${ }^{1}$ Department of Korean Medical Science, ${ }^{2}$ Division of Meridian and Structural Medicine, \\ School of Korean Medicine, Pusan National University
}

\section{행간 전침이 흰쥐 염증성 통증 모델의 통증 행동 완화에 미치는 영향}

\author{
구성태 $^{1,2} \cdot$ 최우영 ${ }^{2}$ \\ 부산대학교 한의학전문대학원 ${ }^{1}$ 한의과학과, ${ }^{2}$ 경락구조의학부
}

\begin{abstract}
Objectives: The present study aimed to examine the analgesic effect of electroacupuncture(EA) applied to the brook point of the Liver meridian in the rat model of inflammatory pain and to investigate involvement of endogenouse opioid in the EA-induced analgesia. Methods : Knee arthritis was induced by injection of $125 \mu 1$ of complete Freund's adjuvant into the knee joint cavity unilaterally. To examine the level of pain, weight bearing forces(WBFs) of affected limb was measured. EA treatment was given at the LR2, LI4 or non-acupoint on the contralateral limb with frequency of $2 \mathrm{~Hz}$ and intensity of $2 \mathrm{~mA}$ under gaseous anesthesia. Results : After induction of arthritis, rats subsequently showed a reduced stepping force of the affected hindlimb due to a painful knee. EA applied to the LR2 point on the contralateral hind limb produced a significant improvement of stepping force of the hind limb lasting for at least $2 \mathrm{~h}$, and this effect was equivalent to that obtained by $5 \mathrm{mg} / \mathrm{kg}$ of oral indomethacin. The effect of EA was specific to the acupoint since it could not be mimicked by EA applied to the LI4 point or the arbitrary non-acupoint. The analgesic effect was blocked by pretreatment with naltrexone $(10 \mathrm{mg} / \mathrm{kg}$, i.p.). Conclusions : These results suggest that acupuncture applied to LR2, brook point of Liver meridian suppresses inflammatory pain in a rat model of knee arthritis and this effect seems to be mediated by endogenous opioid systems.
\end{abstract}

Key words : electroacupuncture, brook point, arthritis, complete freund's adjuvant, opioid

\section{Introduction}

Acupuncture has been used to ameliorate health and is still used to treat many conditions, including chronic and acute pain ${ }^{1)}$. Among the symptoms of arthritis, chronic pain is the most serious and is difficult to treat in a satisfactory manner ${ }^{2}$. To investigate the mechanisms underlying acupuncture analgesia, many studies have been conducted using electroacupuncture(EA) on various experimental animal models ${ }^{3-5)}$. The most significant finding from these studies, perhaps, is that EA-induced analgesia is found to be at least partly reversed by a systemic injection of naloxone, a non-selective opioid antagonist. The result of the early studies suggests that the endogenous opioid system mediates a part of EA-induced

Received September 5, 2017, Revised December 23, 2017, Accepted December 23, 2017

\section{Corresponding author: Sungtae Koo}

Department of Korean Medical Science and Division of Meridian and Structural Medicine, School of Korean Medicine, Pusan National University, 49

Busandaehak-ro, Mulgeum, Yangsan 50612, Korea

Tel: +82-51-510-8474, Fax:+82-51-510-8439, E-mail: stkoo@pusan.ac.kr

This work was supported by a 2-Year Research Grant of Pusan National University.

(c) This is an open access article distributed under the terms of the Creative Commons Attribution Non-Commercial License (http://creativecommons.org/licenses/ by-nc/4.0) which permits unrestricted non-commercial use, distribution, and reproduction in any medium, provided the original work is properly cited. 
analgesia ${ }^{6,7)}$. Furthermore, the naloxone reversible component of the analgesia seems to depend on the frequency of $\mathrm{EA}^{8)}$, suggesting the existence of a specific set of sensory neurons that activate the endogenous opioid system.

In the classical theory of acupuncture, the five transport points are the well, brook, stream, river and sea points of the twelve meridians and one of the most important groups of acupuncture points. The five transport points play an important role in the formation of many acupuncture prescriptions ${ }^{1)}$. Brook point, also known as spring point is the second of the five transport points and is located in the area of the metacarpophalangeal joint of the hand or metatarsophalangeal joint of the foot with the exception of Kidney meridian(KI2). According to the Classic of Difficulties, the brook points are indicated for heat in the body". Because heat along with pain, redness, immobility and swelling is one of key symptoms of inflammation, brook points could be one of options to reduce heat symptom in acupuncture treatment.

To demonstrate the analgesic effect of EA applied to the brook point of Liver meridian in rats, the present study used an arthritis model induced by injection of complete Freund's adjuvant(CFA). CFA arthritis model is a popular laboratory animal model of chronic pain since it has many of the pathological features in common with human rheumatoid $\operatorname{arthritis}(\mathrm{RA})^{10}$. Acupuncture has been offered as an alternative treatment for the chronic pain syndromes related to RA in humans ${ }^{11}$.

Thus, there are few studies to investigate the effects and underlying mechanisms of brook points in the inflammatory pain. In the present study, we aimed to investigate the effect of LR2 on the pain behavior and involvement of endogenous opioids in LR2-induced analgesia in the rat model of inflammatory pain.

\section{Materials and Methods}

\section{Animals}

Male Sprague-Dawley rats(weighing 190 210 g) were housed in cages( $2 \sim 3$ per cage) with soft bedding and were provided free access to food and water under 12 12 hour reversed light-dark cycle(dark cycle: 08:00 20:00). All experimental procedures were carried out in accordance with the Animals(Scientific Procedures) Act 2008(Korea) and all complied with the recommendations of the National Institute of Health's Guide for the Care and Use of Laboratory Animals. The study was also approved by the Ethics Committee on Animal Research at Pusan National University (PNU-2016-1219). The rats were anesthetized under isofluorane anesthesia( $3 \%$ to induce and $1.5 \%$ to maintain in mixed $\mathrm{N}_{2} \mathrm{O} / \mathrm{O}_{2}$ air).

\section{Induction of arthritis}

CFA arthritis was induced by injecting $125 \mu 1$ of a mixture of $62.5 \mu 1$ of saline, and $250 \mu \mathrm{g}$ of suspended heat-killed Mycobacterium butyricum(Difco, Detroit MI, USA) in $62.5 \mu 1$ of incomplete Freund's adjuvant(Difco, Detroit MI, USA) into the synovial cavity of the right knee joint.

\section{Behavioral test}

To evaluate the level of pain in the arthritic knee, we measured the amount of weight bearing by the affected hind limb on rats as our method recently used ${ }^{12)}$. The rat was allowed to walk through a long and harrow acrylic path (width $\times$ height $\times$ length: $10 \times 12 \times 80 \mathrm{~cm}$ ). The rectangular shaped plate of the electronic balance(Sartorius, BP-1200, Germany) was placed to cover a half-width of the floor at the mid way point of the walking path so that only the limbs of one side would step on the balance. The degree of analgesia was expressed as a percentage of relatively improved foot stepping force and was determined as follows:

\section{$\frac{\text { Post-treatment value }- \text { Pre-treatment value }}{\text { Maximum possible value }- \text { Pre-treatment value }} \times 100$}

Maximum possible value was expressed as the foot stepping force on each normal rat's hind limb before the induction of arthritis. Foot stepping force was expressed as weight bearing ratio to body weight.

\section{Electroacupuncture}

Under isoflurane anesthesia, two stainless steel needles 
(0.25 mm diameter, $30 \mathrm{~mm}$ length) mounted on a holder with a 1-mm separation between the tips were inserted into three different points, LR2, LI4 or arbitrary non-acupoint and electrical stimulation was applied by a Grass S88 stimulator(Grass Medical Instruments, Quincy, MI, USA) equipped with the isolator for $30 \mathrm{~min}$. Trains of 4 pulses(10 ms square wave pulses, $50 \mathrm{~Hz}$ of intra-train frequency) repeated at a rate of $2 \mathrm{~Hz}$ were delivered at an intensity of $2 \mathrm{~mA}$. LR2 point was located on the margin of the web between the 1st and 2nd toes. LI4 point was located on the dorsal aspect at the midpoint of the line bisecting the angle between the 1st and 2nd metacarpal bones ${ }^{13)}$. The arbitrary non-acupoint was located on the dorsal aspect of the left foot.

\section{Drugs}

In order to determine whether the effect of EA was mediated by endogenous opioids, naltrexone $(10 \mathrm{mg} / \mathrm{kg}$, Sigma) was intraperitoneally injected $1.5 \mathrm{~h}$ before the beginning of EA. In addition, to assess the effects of indomethacin on the arthritis, 2 and $5 \mathrm{mg} / \mathrm{kg}$ of indomethacin were orally administrated.

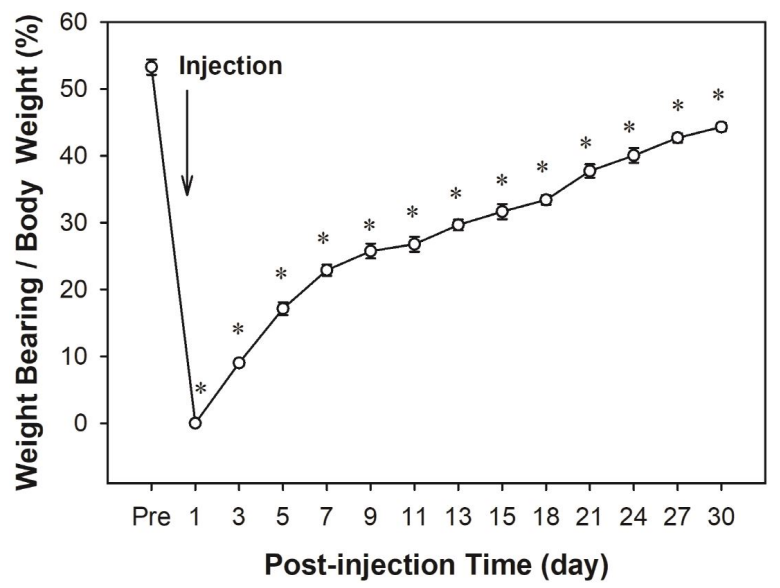

Fig. 1. Changes in weight bearing of the affected hindlimb after the induction of arthritis.

Foot stepping force was measured and expressed as weight bearing ratio to body weight. This shows the average values $( \pm$ SEM) of weight bearing ratio of the hindlimb of a group of 9 rats one hour before(Pre) and at various times after the induction of arthritis. Asterisks indicate values significantly different from the preoperative value(Pre) $(p<0.05$, one-way repeated measures ANOVA followed by Dunnett's post-hoc test).

\section{Statistical analysis}

Data are expressed as mean \pm SEM. Statistical analyses were conducted by the one-way repeated measures analysis of Varience(ANOVA) followed by the Dunnett's post-hoc test, or two-way repeated measures ANOVA followed by the Duncan's all pairwise multiple comparison. A $p$ value of less then 0.05 was considered to be statistically significant.

\section{Results and Discussion}

As shown in Fig. 1, the weight bearing on the normal rat's hind limb reached about 53\% of the rat's total body weight. One day after the induction of arthritis, the stepping force on the affected hind limb was maximally reduced to such an extent that rats did not put any weight on the foot. Once induced, arthritic pain lasted for the next several weeks. We reasoned that the reduced weight bearing on the foot after the induction of knee arthritis was because rats were trying to avoid bearing weight on the affected foot due to pain

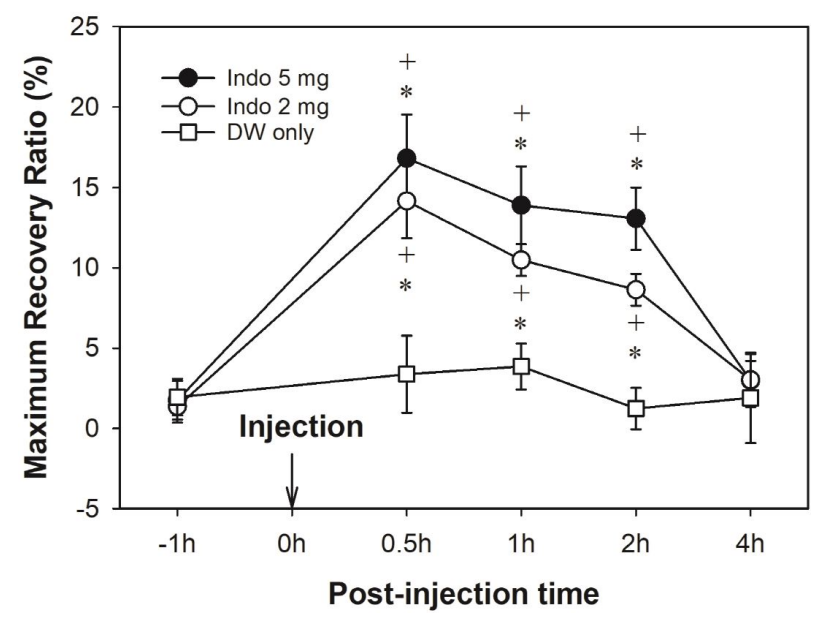

Fig. 2. Effect of indomethacin on weight bearing of the hindlimb in rats with arthritis.

At the 3rd, 4th, and 5th day after the induction of arthritis, either distilled water(DW) alone, $2 \mathrm{mg} / \mathrm{kg}$ of indomethacin(Indo $2 \mathrm{mg}$ ), or $5 \mathrm{mg} / \mathrm{kg}$ of indomethacin(Indo $5 \mathrm{mg}$ ) was orally administrated in random order in different rats in 8 rats with arthritis. Consequently, all 8 rats received each of the three injections on a different day in a randomized crossover manner. Symbols*and + denote values significantly different from the pre-injection value $(-1 \mathrm{~h})$ and from the control(DW) group, respectively $(p<0.05$, two-way repeated measures ANOVA followed by Duncan's multiple comparison). indo; indomethacin. 
associated with the knee arthritis. To evaluate the validity of using the reduction of foot stepping force as an index for arthritic pain, the effect of oral indomethacin on the stepping force was examined. As shown in Fig. 2, administrations of both 2 and $5 \mathrm{mg} / \mathrm{kg}$ of indomethacin significantly restored the reduced foot stepping force for at least $2 \mathrm{~h}$. This effect of indomethacin can be interpreted as producing an analgesic effect so that rats can now put more weight on the foot. To examine the effect of EA on the stepping force, EA was applied to an acupoint for $30 \mathrm{~min}$ under isoflurane anesthesia. As shown in Fig. 3, only EA applied to the LR2 point significantly restored the reduced foot stepping force at a half-, one- and two-hour post-stimulus time points. These data suggest that EA applied to the LR2 point produces an analgesic effect in the knee arthritis pain model. The effect peaks at one hour after the termination of EA and decreases slowly. The magnitude of EA-induced analgesia is equivalent to that obtained by $5 \mathrm{mg} / \mathrm{kg}$ of oral indomethacin. Furthermore, the analgesic effect of EA was occurred in a stimulus point-specific manner. EA applied to the LR2 point produced analgesia but EA applied to LI4 or nearby non-acupoint did

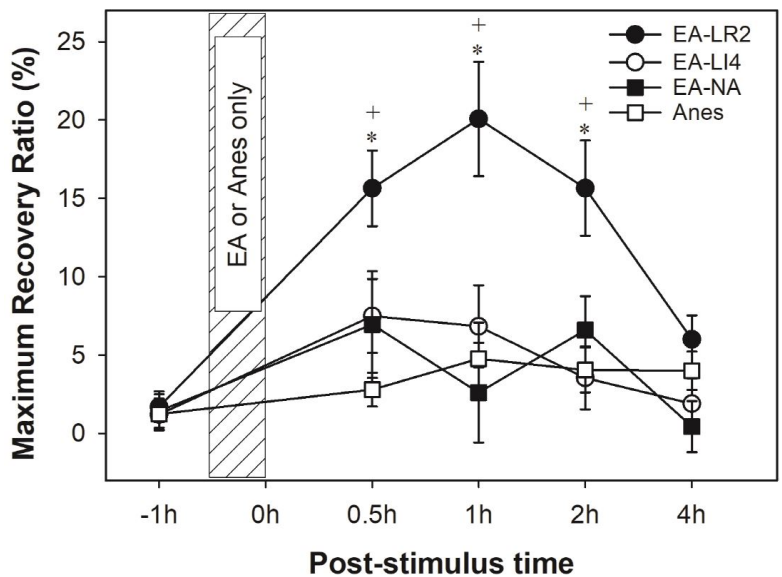

Fig. 3. Effect of EA on weight bearing of the hindlimb in rats with arthritis.

At the 3rd, 4th, 5th and 6th day after the induction of arthritis, either anesthesia alone, EA at the LR2 point, EA at the LI4 point, or EA at the arbitrary non-acupoint(NA) was applied in random order in different rats in 8 rats with arthritis. Consequently, all 8 rats received each of the four procedures in a randomized crossover manner. Symbols*and+denote values significantly different from the pre-stimulus value $(-1 \mathrm{~h})$ and from the control (Anes Only) group, respectively $(p<0.05$, two-way repeated measures ANOVA followed by Duncan's multiple comparison). not. LI4 point is known from previous studies to reduce thermal pain threshold ${ }^{14)}$ and to release endogenous opioids ${ }^{3,6,7)}$. Although LI4 point is known to produce acupuncture analgesia in some conditions, the effect of EA stimulation applied to LI4 in the present study showed no significant difference between anesthesia control group or a non-acupoint group. The different conditions of EA parameter, animal model and/or behavioral test may account for the inconsistent results.

Endogenous opioid hypothesis in acupuncture analgesia proposes that acupuncture stimulation activates the endogenous opioid system to raise the circulating endorphin level. Supporting evidence includes the observation that an injection of naloxone, an opiate antagonist, reverses acupuncture analgesia in mice ${ }^{6}$ as well as in man ${ }^{7}$. Furthermore, naloxone blockade of EA was found to be frequency dependent ${ }^{8)}$ and the effect of EA at different frequencies was mediated by different subtypes of opiate receptors ${ }^{8,15,16}$. It was later found that serotoninergic and noradrenergic pain inhibitory systems play additional roles in acupuncture analgesia ${ }^{17,18)}$.

On the other hand, other studies failed to reverse EA induced analgesia by opiate antagonists, such as naloxone or

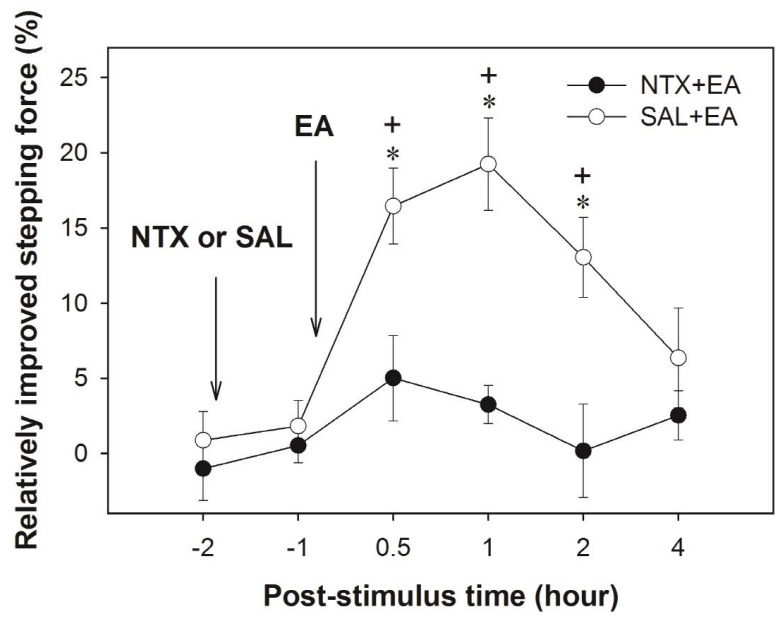

Fig. 4. Effect of naltrexone on EA-induced analgesia.

8 rats were randomly divided into two groups. In one group of 4 rats, EA was applied to the LR-2 point $1.5 \mathrm{~h}$ after the injection of naltrexone. In other group of 4 rats, EA was applied to the LR-2 point $1.5 \mathrm{~h}$ after the injection of saline. Therefore, all 8 rats received naltrexone and saline with EA within 2 days in a randomized crossover manner. Symbols*and+denote values significantly different from the pre-treatment value $(-1 \mathrm{~h})$ and from NTX+EA group, respectively $(p<0.05$, two-way repeated measures ANOVA followed by Duncan's multiple comparison). 


\section{KOREAN JOURNAL OF ACUPUNCTURE}

naltrexone, in rabbits ${ }^{19)}$, in rats ${ }^{5,12)}$, or in humans ${ }^{20}$. Furthermore, opiate antagonists sometimes potentiate EA analgesia in rats ${ }^{5,21}$. Therefore, the issue of whether or not EA induced analgesia is mediated by endogenous opioids is not completely settled.

The effect of pretreatment with naltrexone on the analgesic effect of EA was examined. As shown in Fig. 4, EA applied to the LR2 point significantly restored the reduced foot stepping force in only saline-pretreated arthritis rats. These data suggest that the effect of EA can be blocked by naltrexone. Using the knee arthritis model, we demonstrated that EA produced a long lasting analgesic effect and the effect of EA could be mediated by the endogenous opioid system. Results of present study is in line with the findings that acupuncture can alleviate the knee pain associated with the development of $\mathrm{RA}^{22,23)}$. In addition, the present results is consistent with the facts that the analgesic effect of $\mathrm{EA}$ is mediated by endogenous opioids ${ }^{6,724)}$.

The reduced weight bearing in the arthritis is one of the most commonly observed functional disabilities in arthritic animals and humans. In this study, we measured the weight bearing by the affected limb to assess the level of pain in the arthritis ${ }^{25,26}$. Previously, Min et al. ${ }^{25)}$ measured changes in weight bearing of the foot by having rat voluntarily walk through a chamber. They used this method in rats with acute and mild arthritis recovered relatively quickly( 3 days) while we used it in rats with chronic and severe arthritis lasting for the several weeks. These facts suggest that this technique is useful for the assessment of both acute and chronic arthritis models. However, it was difficult to measure the effects of analgesic treatments for arthritic pain within 2 days after the induction of CFA arthritis, since at those periods the level of pain was so severe that rats could not put any weight on the hind limb.

\section{Conclusion}

In summary, we demonstrated the analgesic effect of EA applied to brook point of the Liver meridian on the knee
LR2 Ameliorates Inflammatory Pain in Rats

arthritis pain model. The effect lasted for at least $2 \mathrm{~h}$ after the termination of EA and the magnitude of the peak effect was equivalent to that obtained by $5 \mathrm{mg} / \mathrm{kg}$ of oral indomethacin. The analgesic effect was induced by EA applied to the acupoint remote from the affected limb in a stimulus point-specific manner. Furthermore, the effect of EA was likely mediated by endogenous opioid system.

\section{Acknowledgements}

This work was supported by a 2-Year Research Grant of Pusan National University.

\section{References}

1. Deadman P, Al-Khafaji M, Baker K. A Manual of Acupuncture. Hove: Journal of Chinese Medicine Publications. 2007.

2. Burckhardt CS. The use of the McGill Pain Questionnaire in assessing arthritis pain. Pain. 1984; 19 : 305-14.

3. Cheng RS, Pomeranz B. Monoaminergic mechanism of electroacupuncture analgesia. Brain Res. $1981 ; 215$ : 77-92.

4. Han J-s, Zhou Z-f, Xuan Y-t. Acupuncture has an analgesic effect in rabbits. Pain. $1983 ; 15: 83-91$.

5. Bossut DF, Huang ZS, Sun SL, Mayer DJ. Electroacupuncture in rats: evidence for naloxone and naltrexone potentiation of analgesia. Brain Res. 1991 ; 549 : 36-46.

6. Pomeranz B, Chiu D. Naloxone blockade of acupuncture analgesia: endorphin implicated. Life Sciences. 1976; 19: 1757-62.

7. Mayer DJ, Price DD, Rafii A. Antagonism of acupuncture analgesia in man by the narcotic antagonist naloxone. Brain Res. $1977 ; 121: 368-72$.

8. Han JS. Acupuncture: neuropeptide release produced by electrical stimulation of different frequencies. Trends Neurosci. $2003 ; 26: 17-22$.

9. Meridians and Acupoints Compilation Committee of Korean Medical Colleges. Principles of Meridians \& Acupoints; A Guidebook for College Students. Daejeon: JongRyeoNaMu Publishing Co. 2015. 
10. Colpaert FC. Evidence that adjuvant arthritis in the rat is associated with chronic pain. Pain. 1987; $28: 201-22$.

11. Struthers GR, Scott DL, Scott DG. The use of 'alternative treatments' by patients with rheumatoid arthritis. Rheumatology international. $1983 ; 3: 151-2$.

12. Koo ST, Park YI, Lim KS, Chung K, Chung JM. Acupuncture analgesia in a new rat model of ankle sprain pain. Pain. 2002 ; 99 : 423-31.

13. Stux G, Pomeranz B. Acupuncture Textbook and Atlas. Berlin Heidelberg New York Tokyo: Springer-Verlag. 1987.

14. Qiao LN, Liu JL, Tan LH, Yang HL, Zhai X, Yang YS. Effect of electroacupuncture on thermal pain threshold and expression of calcitonin-gene related peptide, substance $P$ and gamma-aminobutyric acid in the cervical dorsal root ganglion of rats with incisional neck pain. Acupunct Med. 2017 ; 35 : 276-83.

15. Chen XH, Han JS. Analgesia induced by electroacupuncture of different frequencies is mediated by different types of opioid receptors: another cross-tolerance study. Behav Brain Res. $1992 ; 47: 143-9$.

16. Chen XH, Geller EB, Adler MW. Electrical stimulation at traditional acupuncture sites in periphery produces brain opioidreceptor-mediated antinociception in rats. J Pharmacol Exp Ther. 1996 ; 277 : 654-60.

17. Zhang R, Lao L, Ren K, Berman BM. Mechanisms of acupuncture-electroacupuncture on persistent pain. Anesthesiology. $2014 ; 120: 482-503$.

18. Mayer DJ. Biological mechanisms of acupuncture. Prog Brain
Res. 2000 ; 122 : 457-77.

19. McLennan H, Gilfillan K, Heap Y. Some pharmacological observations on the analgesia induced by acupuncture in rabbits. Pain. 1977 ; 3 : 229-38.

20. Chapman CR, Benedetti C, Colpitts YH, Gerlach R. Naloxone fails to reverse pain thresholds elevated by acupuncture: acupuncture analgesia reconsidered. Pain. 1983; $16: 13-31$.

21. Das S, Chatterjee TK, Ganguly A, Ghosh JJ. Role of adrenal steroids on electroacupuncture analgesia and on antagonising potency of naloxone. Pain. $1984 ; 18: 135-43$.

22. Arichi S, Arichi H, Toda S. Acupuncture and rehabilitation(III) effects of acupuncture applied to the normal side on osteoarthritis deformans and rheumatoid arthritis of the knee and on disorders in motility of the knee joint after cerebral hemorrhage and thrombosis. Am J Chin Med. 1983; 11 : 146-9.

23. Man SC, Baragar FD. Preliminary clinical study of acupuncture in rheumatoid arthritis. J Rheumatol. $1974 ; 1:$ 126-9.

24. Cheng RS, Pomeranz BH. Electroacupuncture analgesia is mediated by stereospecific opiate receptors and is reversed by antagonists of type I receptors. Life Sci. 1980 ; 26 : 631-8.

25. Min SS, Han JS, Kim YI, Na HS, Yoon YW, Hong SK et al. A novel method for convenient assessment of arthritic pain in voluntarily walking rats. Neurosci Lett. $2001 ; 308: 95-8$.

26. Schott E, Berge OG, Angeby-Moller K, Hammarstrom G, Dalsgaard CJ, Brodin E. Weight bearing as an objective measure of arthritic pain in the rat. J Pharmacol Toxicol Methods. 1994 ; $31: 79-83$.

\section{국문초록}

목적 : 이 연구는 흰쥐 염증성 통증 모델에서 족궐음간경의 형혈 전침의 진통효과를 조사하고 이 전침의 진통효과에 내인성 오피오이드가 관 계되어 있는지 조사하고자 하였다. 방법 : 무릎 관절염은 $125 \mu l$ complete Freund's adjuvant를 흰쥐의 한쪽 무릎관절강에 주입하여 유도하 였다. 통증 정도를 검사하기 위해 관절염을 유도한 쪽 뒷다리의 weight bearing forces(WBFs)를 측정하였다. 전침은 건측 행간, 합곡, 또는 뒷다리의 비경혈에 가스 마취하에서 $2 \mathrm{~Hz}, 2 \mathrm{~mA}$ 자극조건으로 처치하였다. 결과 : 관절염을 유도한 이후에, 점차적으로 무릎에 통증이 증가하 기 때문에 관절염을 유발한 쪽 뒷발로 딛는 압력이 감소하였다. 건측 행간에 전침 자극을 한 군에서 전침 자극 후 최소 2시간까지 유의하게 WBF가 증가하였으며, 이 효과는 구강으로 투여한 indomethacin $5 \mathrm{mg} / \mathrm{kg}$ 의 효과에 해당하였으며, 이 전침의 효과는 합곡이나 비경혈에서는 나타나지 않았다. 아울러 이 진통효과는 오피오이드 길항제인naltrexone $(10 \mathrm{mg} / \mathrm{kg}, \mathrm{i} . \mathrm{p}$.)을 전처치했을 때 차단되었다. 결론 : 이상의 결과는 족궐음간경의 형혈인 행간 자침이 흰쥐 관절염 모델에서 염증성 통증을 억제하는 효과가 있음을 보여주며, 이 효과는 내인성 오피오이드 시스 템이 매개하는 것으로 보인다.

Key words: 전침, 형혈, 관절염, 완전 프로인트 어쥬번트, 오피오이드 